\title{
MANAJEMEN SISTEM MONITORING PEMBAYARAN HUTANG PEMBELIAN UNTUK ESTIMASI PENGELUARAN SEBAGAI PENDUKUNG KEPUTUSAN
}

\author{
Janu Ilham Saputro ${ }^{1}$ \\ Dedi Martono ${ }^{2}$ \\ Siti Sunariah ${ }^{3}$ \\ Dosen STMIK Raharja ${ }^{1,2}$, STMIK Raharja Jurusan Teknik Informatika ${ }^{3}$ \\ Jl. Jendral Sudirman No. 40, Modern Cikokol, Tangerang \\ Email:janu@raharja.info ${ }^{1)}$, dedi@raharja.info ${ }^{2)}$, siti.sunariah@ raharja.info $^{3)}$
}

\begin{abstract}
ABSTRAK
Perkembangan teknologi informasi belakangan ini mengalami perkembangan yang begitu pesat, hal ini diikuti dengan berkembangnya media informasi yang terus bertambah. Perusahaan selalu dituntut untuk mengikuti perkembangan ini dalam rangka peningkatan kualitas pelayanan dan kinerja perusahaan. Saat ini diberbagai perusahaan dituntut untuk melakukan pembayaran pajak sesuai aturan yang telah ditentukan sebagai bentuk kewajiban perusahaan kepada negara. Permasalahan yang sering terjadi diperusahaan adalah tidak terkontrolnya po dan faktur pajak, sehingga sering kali terjadi kelebihan pembayaran hutang pajak dari yang seharusnya, dan hal ini menyebabkan keterlambatan dalam pengambilan keputusan, sehingga perencanaan keuangan dalam pembayaran hutang pembelian. Untuk dapat mengatasi masalah ini diperlukan suatu sistem terkomputerisasi yang mampu memonitoring sistem perhitungan hutang pembelian sebagai pendukung keputusan untuk estimasi pengeluaran. Untuk dapat mewujudkan ini diperlukan beberapa langkah perancangan dengan menganalisa prosedur yang berjalan, membangun rancangan sistem dengan usecase diagram, activity diagram, squen diagram dan rancangan class diagram sebagai bentuk pusat penyimpanan data yang kemudian dapat diolah secara otomatis sehingga menjadi dasar pengambilan keputusan. Kemudian diimplementasikan dengan membangun sebuah sistem berbasis web yang dapat dimanfaatkan diperusahaan. Manfaat yang diharapkan adalah terciptanya sistem yang mampu berjalan secara efektif dan efisien, sekaligus mampu mencetak laporan dengan cepat dan akurat, sehingga bisa mengurangi permasalahan yang sering terjadi di perusahaan.
\end{abstract}

Kata kunci: monitoring pembayaran, hutang pembelian, estimasi pengeluaran

\begin{abstract}
The development of information technology has recently experienced such rapid development, this is followed by the development of information media that continues to grow. Companies are always required to follow this development in order to improve service quality and company performance. At present, various companies are required to pay taxes according to the rules that have been determined as a form of the company's obligation to the state. Problems that often occur in the company are uncontrolled po and tax invoices, so that often there is an overpayment of tax debt from what should be, and this causes delays in decision making, so that financial planning in payment of purchase debt. To be able to overcome this problem, a computerized system is needed to monitor the purchase debt calculation system as a decision support for expenditure estimation. To be able to realize this, it takes several design steps by analyzing the procedures that are running, building a system design with usecase diagrams, activity diagrams, squen diagrams and class diagram designs as a form of data storage center which can then be processed automatically so that it becomes the basis for decision making. Then implemented by building a web-based system that can be used in the company. The expected benefits are the creation of a system that is able to run effectively and efficiently, as well as being able to print reports quickly and accurately, so as to reduce problems that often occur in the company.
\end{abstract}

Keywords: payment monitoring, purchase debt, estimated expenditure 


\section{PENDAHULUAN}

Seiring perkembangan teknologi informasi yang terus mengalami kemaujuan yang sangat pesat, saat ini banyak sekali hal-hal baru yang diciptakan untuk membantu orang lain dalam mempermudah pekerjaan. Dalam rangka peningkatkan kinerja serta kualitas pelayanan pada suatu perusahaan, salah satu faktornya adalah penerapan sistem informasi berbasis komputer. Sistem merupakan sarana yang menjadi acuan untuk kinerja berjalanya pencatatan pembukuan perusahaan agar berjalan dengan baik. Sistem informasi tidak boleh diabaikan, karena merupakan salah satu kunci utama untuk mendorong perkembangan perusahaan. Pada saat ini perusahaan terkadang mengalami kesulitan dalam memonitoring hutang dagang atau tagihan supplier, sehingga memerlukan sistem informasi untuk mendukung perusahaan dalam pengambilan keputusan.

Beberapa perusahaan masih menggunakan microsoft excel, selain itu juga tidak terdapat notifikasi atau kontrol khusus sebagai peringatan, purchase order dan faktur pajak tidak terkontrol, sehingga sering kali terjadi kelebihan pembayaran hutang pajak dari yang seharusnya, dan hal ini menyebabkan keterlambatan dalam pengambilan keputusan. Terjadinya beberpa masalah yang dialami dalam keadaan darurat yang disebabkan adanya kesalahan informasi antara dept finance, dept purchasing dan manager keuangan, sehingga mengalami kesulitan mendapatkan informasi mengenai pembayaran purchase order, yang meliputi informasi seberapa banyak purchase order yang sudah di buat dan purchase order mana saja yang harus jadwalkan untuk dibayarkan sesuai tanggal jatuh tempo. Sehingga perencanaan pengeluaran bulanan yang terkait dengan tanggal jatuh tempo hutang dagang tidak termonitoring dan tidak terupdate dengan baik yang mengakibatkan terhambatnya proses administrasi dan kegiatan lainya yang dilakukan di perusahaan. Informasi hutang pembelian sebagai dasar untuk pengambilan keputusan dalam perencanaan dan pelaksanaan proses pembayaran tersebut.

Suatu sistem yang terotomatisasi dapat membantu petugas dalam menyelesaikan kewajibanya dangan lebih cepat sehingga mengurangi tingkat keterlambatan yang akan mengganggu stabilitas perusahaan. [1] Pembayaran adalah pelunasan utang oleh debitur kepada kreditur bisa dilakukan dalam bentuk uang atau barang. [2] Hutang pembelian merupakan tagihan yang ditagihkan oleh supplier atas pemesanan barang yang telah dilakukan sebelumnya berdasakan purchase order. Biasanya masa waktu pembayaran memliki jatuh tempo yang diberikan cukup bervrian yaitu pembayaran cash dan maksimal 30 hari.

Sistem pembayaran adalah sistem yang mencakup seperangkat aturan, lembaga, dan mekanisme yang digunakan untuk melaksanakan pemindahan dana guna memenuhi suatu kewajiban yang timbul dari suatu kegiatan ekonomi (UU tentang Bank Indonesia pasal 1, angka 6). Dari sisi perkembanganya sistem pembayaran tentu saja memberikan manfaat dan kebutuhan bagi para pengguna,seperti pada sekolah dalam mendukung kegiatan ekonominya dalam pengalokasian dana terhadap kemajuan sekolah tersebut baik didalam organisasi maupun diluar organisasi. [5]

Sistem pembayaran juga terdiri dari serangkaian sub-sistem atau sub komponen (alat pembayaran, kelembagaan, infrastuktur) yang secara bersama-sama membentuk suatu kesatuan yang diperlukan dalam perpindahan nilai uang (transfer of value) dari satu pihak ke pihak lainya perpindahan dana dalam berbagai pengertian sistem tersebut bisa dilakukan dalam bentuk yang sederhana yang hanya melibatkan dua pihak/individu secara langsung. Kebutuhan akan suatu sistem komputerisasi pada zaman sekarang ini mencakup kesegala 
bidang yang berhubungan dengan penerapan teknologi informasi. Setiap perusahaan swasta maupun pemerintahan sangat membutuhkan sistem komputerisasi yang relevan, akurat, cepat, dan efisien. [6] Ketersediaan informasi yang cepat dan akurat serta didukung dengan penerapan sistem yang optimal menjadi kelebihan sendiri harus dimiliki setiap perusahaan. [3] Perancangan Sistem adalah suatu kegiatan membuat desain teknis berdasarkan kegiatan pada waktu proses analisis. Perancangan disini dimaksudkan suatu proses pemahaman dan peran suatu sistem informasi berbasis komputer. [7] Monitoring adalah kegiatan memantau yang dilakukan secara rutin mengenai kemajuan project yang sedang berjalan atau kegiatan memantau perubahan proses dan output project.[6]

\section{METODE PENELITIAN}

Metode penelitian merupakan suatu tata cara atau kegiatan pelaksanaan penelitian rangka untuk mengumpulkan informasi atau data serta melakukan investigasi terhadap data yang telah didapatkan tersebut. yang didasari oleh asumsi-asumsi dasar, pandanganpandangan filosofis dan ideologis, pertanyaan dan isu-isu yang dihadapi. Suatu penelitian mempunyai rancangan penelitian tertentu. Rancangan ini menggambarkan prosedur atau langkah-langkah yang harus ditempuh, waktu penelitian, sumber data dan kondisi arti untuk apa data dikumpulkan dan dengan cara bagaimana data tersebut dihimpun dan diolah untuk dianalisa dalam pembuatan laporan.

\subsection{Metode Observasi (Observasi Research)}

Pada tahapan ini penulis melakukan pengamatan langsung dari objek penelitian untuk mendapatkan data dan informasi yang akurat dan lengkap dari berbagai pihak yang terkait dan berhubungan dengan tema penelitian yang berhasil penulis rumuskan di bagian finance.

\section{a. Metode Wawancara (Interview Research)}

Penulis melakukan wawancara Manager Keuangan dan Purchasing yang mengolah data keuangan, penulis mendapatkan informasi berkaitan dengan penelitian penulis.

\section{b. Metode Studi Pustaka (Studi Literature)}

Selain melakukan Observasi penulis juga melakukan data dengan cara studi pustaka dalam metode ini penulis berusaha untuk melengkapi data-data yang diperoleh dengan membaca dan mempelajari dari buku-buku dan data-data yang relevan dalam pemilihan judul yang penulis ajukan. Buku dan data tersebut digunakan penulis untuk membantu penganalisaan dan perancangan yang dilakukan.

\subsection{Metode Analisis Data}

Pada penelitian ini, metode analisa dilakukan dengan langkah-langkah melakukan pengamatan dan analisa terhadap sistem yang berjalan saat ini, serta menentukan UML (Unified Modeling Language) yang meliputi use case diagram, activity diagram, sequence diagram.

\section{PEMBAHASAN}

Untuk dapat menggambarkan prosedur secara keseluruhan diperlukan bebrapa tahapan analisa sebagai bentuk pengumpulan informasi guna mendapatkan model yang sesuai dengan kebutuhan dan mampu memberikan solusi dengan cepat secara efektif dan efisien, mulai dari 
tahapan pengumpulan informasi dan kebutuhan, analisa dokumen, merancangan hubungan antar dokumen sampai dengan merancanga model diagram database dan model rancangan sistem. Beberapa tahapan yang dimaksud sampai dengan model ranangan yang diciptakan dapat dilihat pada gambar 1,2,3,4,4.

\subsection{Use Case Diagram Prosedur Berjalan}

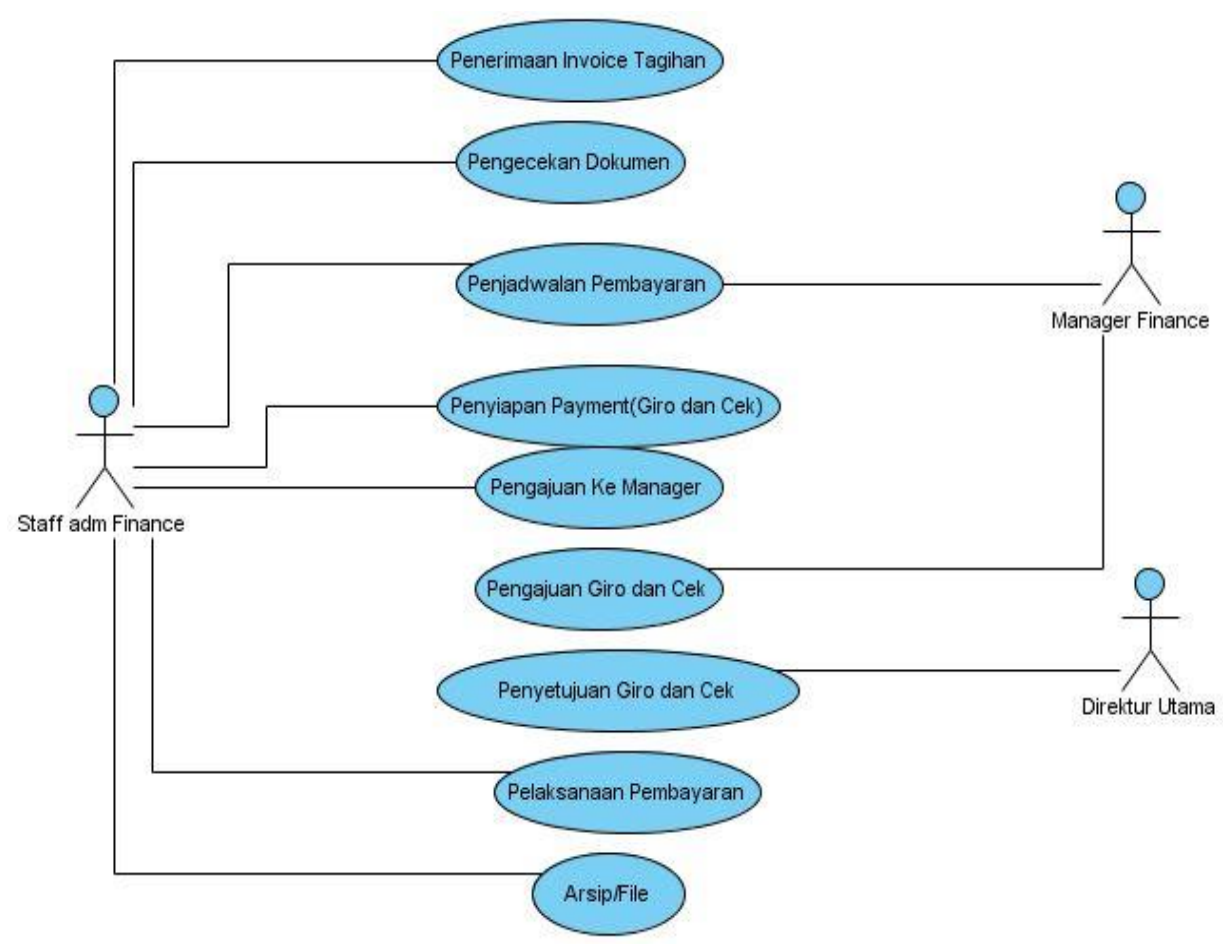

Gambar 1. Use Case Diagram

Berdasarkan gambar use case Diagram (gambar 1) yang berjalan saat ini sistem yang mencakup seluruh kegiatan pada sistem pelaporan hutang dagang. Terdapat 3 (tiga) Actor yang melakukan kegiatan yaitu staff admin finance yang berfungsi menangani invoice tagihan, pengecekan dokumen, penjadwalan pembayaran, penyiapan payment giro dan cek, pengajuan ke manager, pelaksanaan pembayaran dan pengarsipan file.

Terdapat juga 9 (sembilan) use case yang merupakan proses yang terjadi pada sistem berjalan yaitu menerima invoice tagihan yang melibatkan admin finance, pengecek dokumen terkait: purchase order, surat jalan, faktur pajak yang melibatkan admin finance, penjadwalan pembayaran manager keuangan yang mengatur penjadwalan pembayaran dan mmberikan informasi kepada staff admin finance, kemudian pengajuan dokumen dari staff admin finance ke manager keuangan, selanjutnya pengajuan cek dan giro yang diajukan oleh staff admin finance ke manager keuangan serta direktur utama, pelaksanaan pembayaran yang dilakukan oleh staff admin finance kemudian seluruh dokumen akan arsip. 


\subsection{Activity Diagram Prosedur Berjalan}

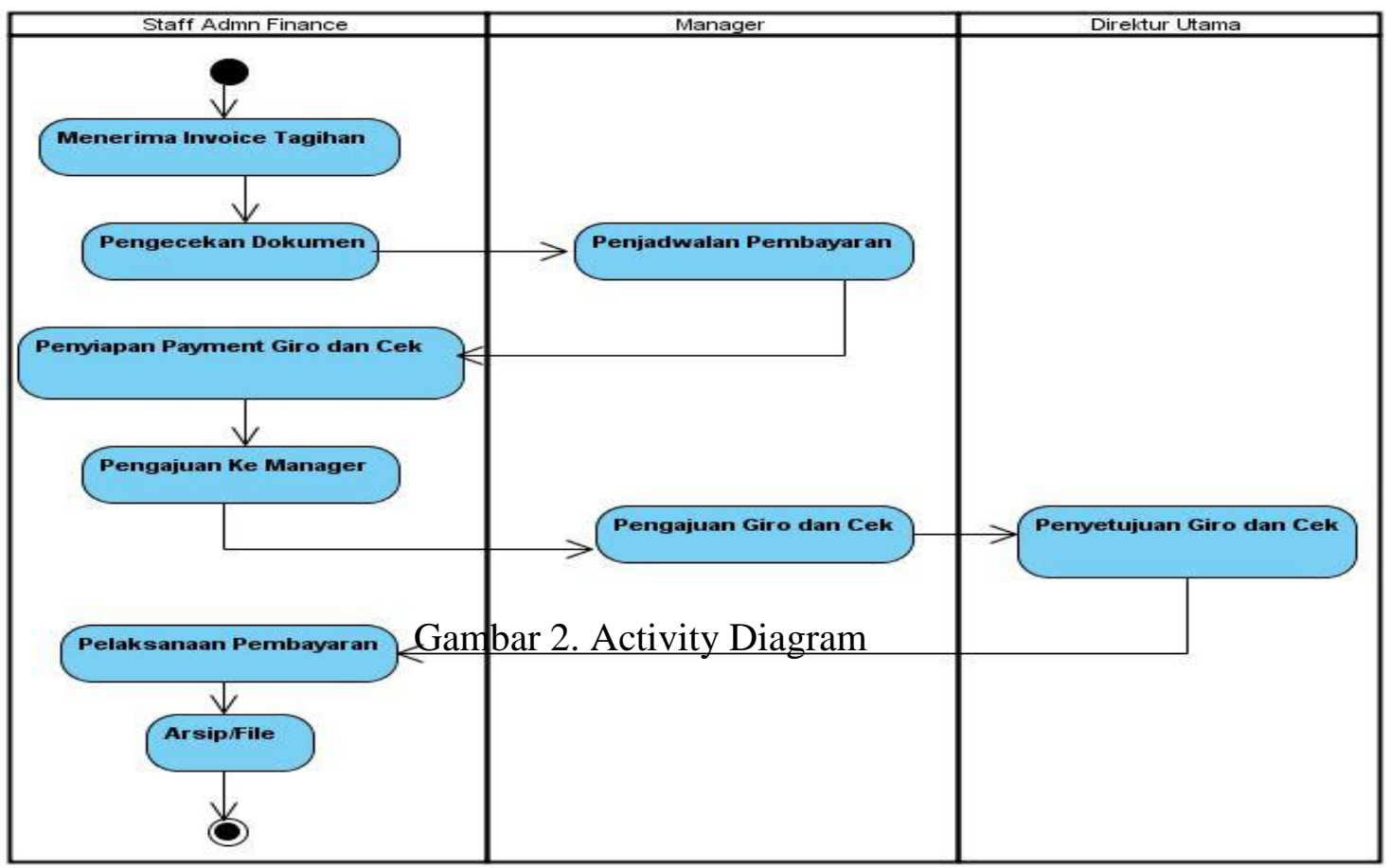

Gambar 2. Activity Diagram

Berdasarkan gambar activity diagram (gambar 2) yang berjalan saat ini sistem mencakup seluruh kegiatan pelaporan hutang dagang. Sistem ini melibatkan 3 (tiga) Actor yaitu, staff admin finance yang menangani penerimaan invoice, kemudian pengecekan dokumen, penjadwalan pembayaran akan dilakukan oleh manager keuangan untuk kemudian disiapkan payment giro dan cek dan melakukan pengajuan ke manager keuangan yang akan ditanda tangani oleh direktur utama, setelah di tanda tangani maka pembayaran tersebut dilaksananan kemudian file dokumen tersebut diarsipkan.

\subsection{Squence Diagram Prosedur Berjalan}

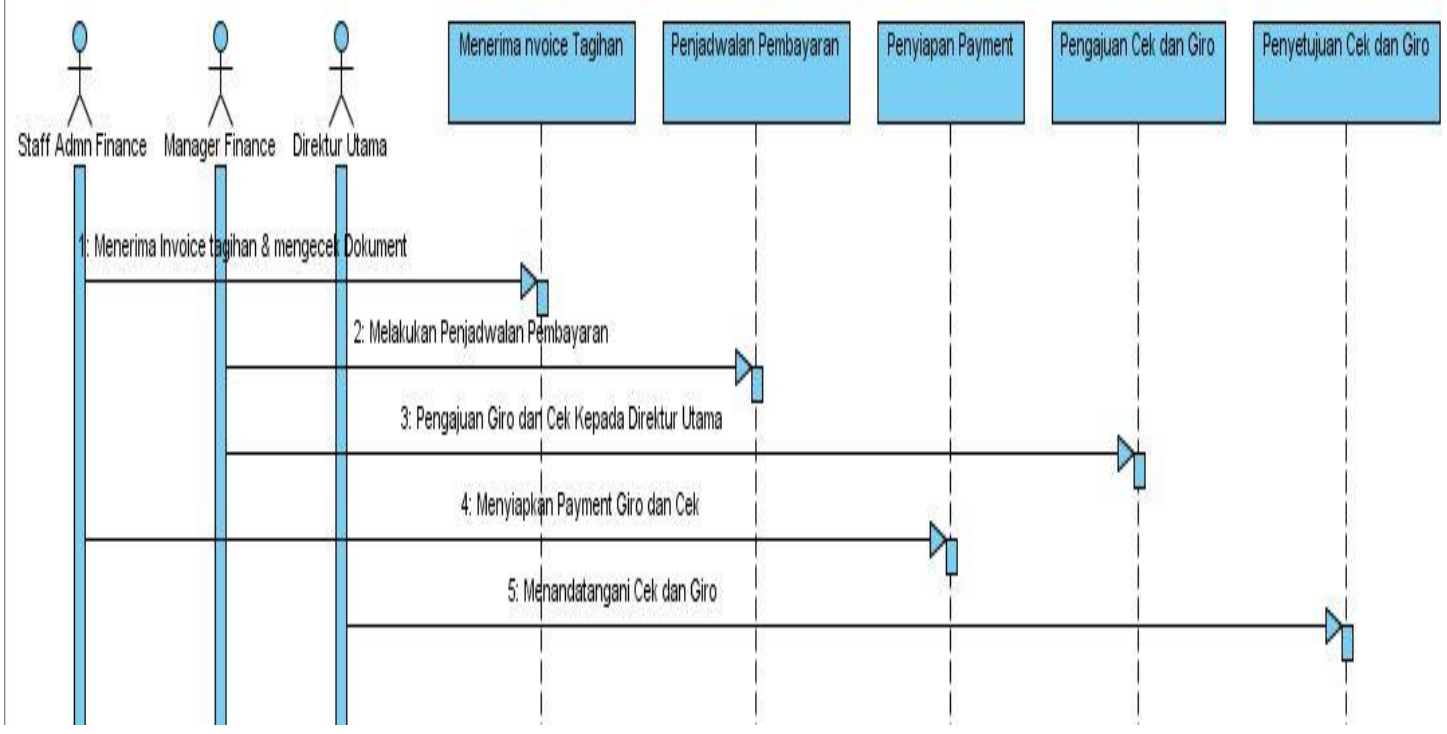

Gambar 3. Squence Diagram 
Berdasarkan gambar sequence diagram (gambar 3) yang berjalan saat ini terlihat 3 (tiga) actor yang melakukan kegiatan diantaranya: staff admin finance, manager keuangan dan direktur utama, yang akan menyelesaikan 5 message spesifikasi dari komunikasi antar objek yang memuat informasi-informasi tentang aktifitas yang terjadi, yaitu penerimaan invoice tagihan, penjadwalan pembayaran, menyiapkan payment, pengajuan cek dan giro, penandatanganan cek dan giro.

Rancangan diatas (gambar 1, 2, 3) merupakan gambaran prosedur yang berjalan dimana pada tahapan ini melibatkan beberapa dokumen seperti po, surat jalan, id card, invoice, faktur pajak, dan tanda terima invoice. Dimana po dibuat oleh user yang berfungsi sebagai tanda bukti pesanan yang telah dibuat dan kuat setelah ditanda tangani yang dikirim ke supplier. Surat jalan yang dibuat oleh supplier yang befungsi sebagai bukti bahwa barang telah dikirim dan diterima oleh customer. Id card merupakan tanda pengenal karyawan. Invoice dibuat oleh supplier yang berfungsi sebagai tagihan yang berdasarkan pemesanan po dan surat jalan, faktur paktur jalan dibuat oleh supplier berdasarkan invoice yang dibuat jika barang tersebut dikenakan pajak . Tanda terima invoice dibuat oleh costumer yang berfungsi sebagai bukti bahwa invoice tersebut sudah diterima dan dibuat sebagai acuan tanggal jatuh tempo.

\subsection{Class Diagram}

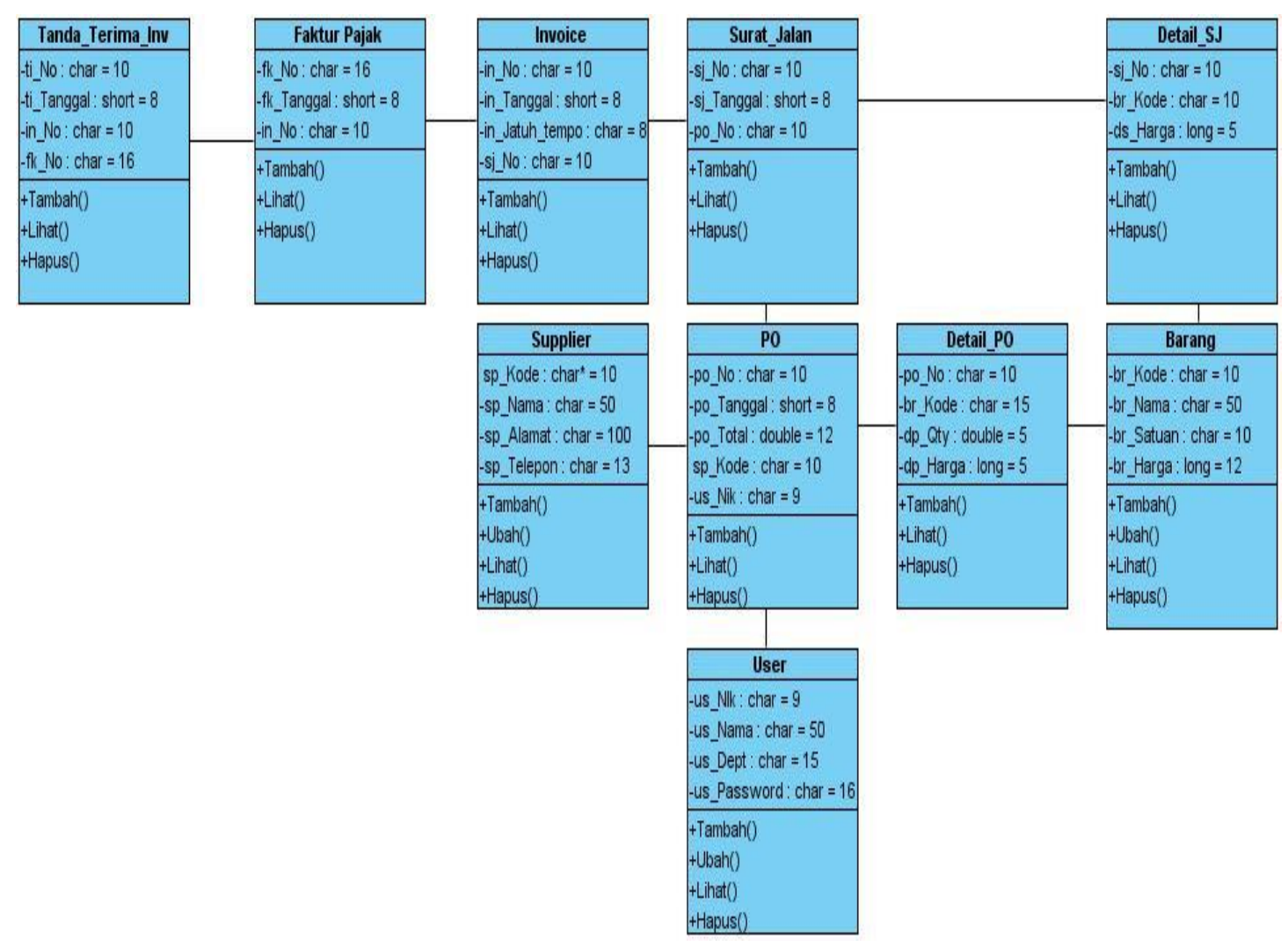

Gambar 4. Class Diagram

Berdasarkan gambar class diagram (gambar 4) yang berjalan saat ini sistem yang mencakup seluruh kegiatan pada sistem pelaporan hutang dagang. Terdapat 10 (sepuluh) class yaitu user, barang, supplier yang merupakan tabel master dan po, surat_jalan, invoice, faktur_pajak, tanda_terima_invoice sebagai tabel transaksi, serta tabel detail_sj yang tercipta 
karena adanya tabel surat_jalan, tabel detail_po yang tercipta karena adanya tabel po dan merupakan tabel histori.

Berdasarkan gambar class diagram (gambar 4) diatas dapat dilihat dengan jelas bahwa tingkat hubungan po dan surat_jalan yaitu one to many (1:M), tingkat hubungan supplier dan po one to many (1:M), tabel detail_po tercipta karena adanya tingkat hubungan many to many (M:M) antara tabel po dan tabel barang. tabel detail_sj tercipta karena adanya tingkat hubungan many to many (M:M) antara tabel barang dan tabel surat_jalan. Tingkat hubungan user dan po yaitu one to many (1:M). Tingkat hubungan surat_jalan dan invoice yatu many to one (M:1), tingkat hubungan invoice dan faktur_pajak yaitu one to one (1:1). Tingkat hubungan faktur_pajak dan tanda_terima_invoice yaitu one to one (1:1).

\subsection{Use Case Diagram Usulan}

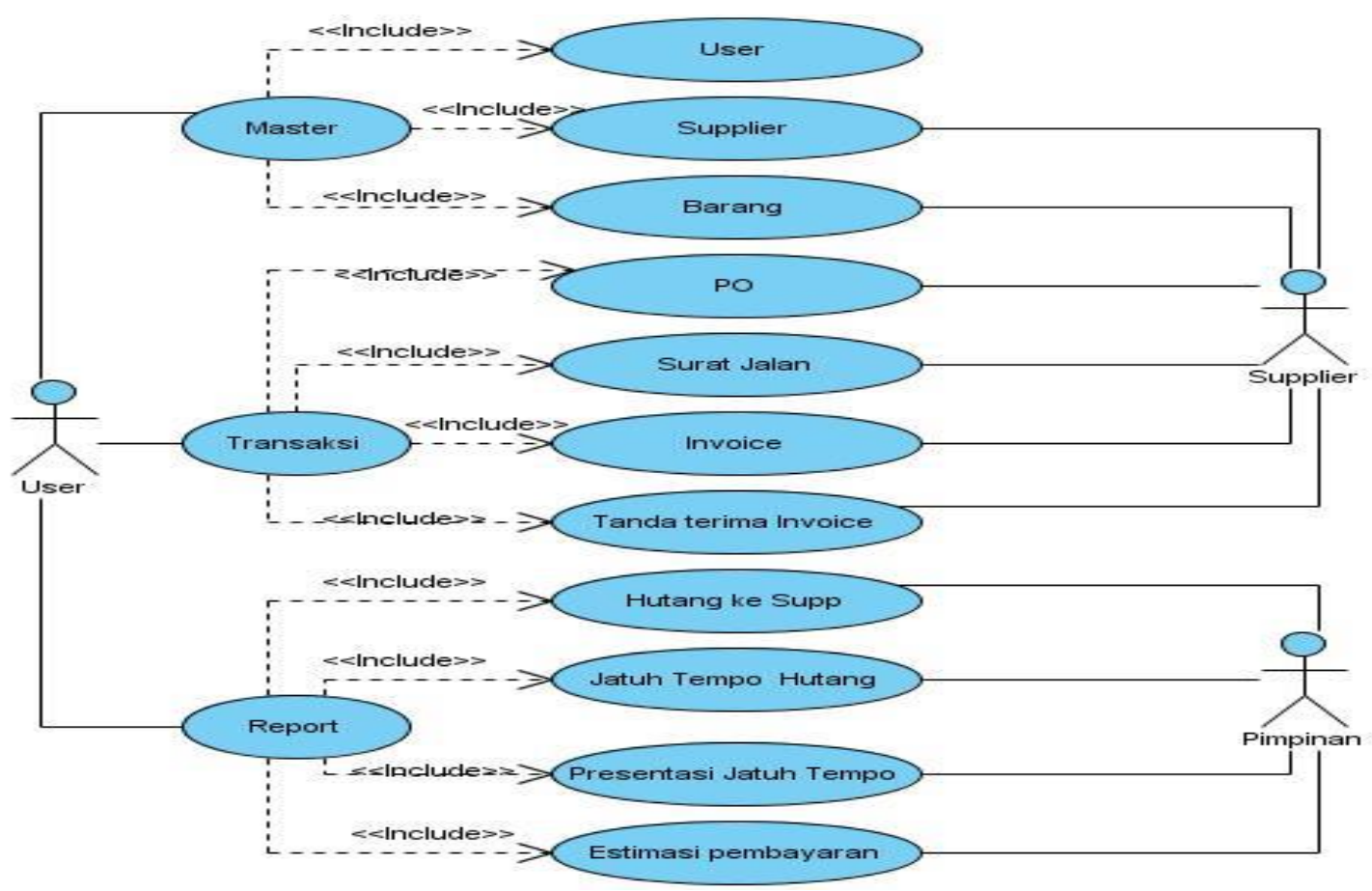

Gambar 5. Use Case Diagram

Berdasarkan gambar use case diagram usulan (gambar 5) terlihat jelas bahwa terdapat 11 (sebelas) use case yang terdiri dari 3 (tiga) use case utama yaitu master, transaksi, report. Use case master memiliki 3 (tiga) yang terdiri dari user yang terhubung dengan actor user, barang, supplier berhubungan dengan actor user dan actor supplier. Use case transaksi memiliki 4 (empat) yang terdiri dari po, surat jalan, invoice, tanda terima invoice, yang terhubung dengan actor user dan supplier. Use case report memiliki 4 (empat) yang terdiri dari hutang ke supplier, jatuh tempo hutang, presentasi jatuh tempo, estimasi pembayaran yang terhubung dengan actor user dengan pimpinan.

Use diagram sebagai bentuk rancangan sistem yang akan diciptakan (gambar 5) merupakan desain model tampilan utama yang berorintasi pada kebutuhan menu pada aplikasi yang disiapkan, selain itu untuk kebutuhan penyimanan informasi data agar dapat digunakan secara histori juga digambarkan dalam bentuk class diagram (gambar 4) lengkap dengan informasi field dan type data sesuai kebutuhan penyimpanan data. 


\section{IMPLEMENTASI}

\subsection{Rancangan Basis Data}

Untuk dapat menggamarkan bentuk basis data secara utuh, peneliti penggunakan aplikasi microsoft access sebagai bentuk gambaran dasar, dan pada akhirnya bentuk rancangan basis data ini dapat disesuaikan menggunakan apa saja sesuai kebutuhan.

a. Tabel Master: User

Primary Key : us_Nik

Foreign Key : -

Structure Tabel : \{ us_Nik, us_Nama, us_Depart, us_Password \}

\begin{tabular}{|l|l|l|}
\hline Hs_Nik & \multicolumn{2}{c|}{ Data Type } \\
\hline us_Nama & Text & Nomor induk karyawan \\
\hline us_Depart & Text & Nama Karyawan \\
\hline us_Password & Text & Departement / bagian \\
\hline
\end{tabular}

Tabel 1. Struktur User

b. Tabel Master: Supplier

Primary Key : sp_Kode

Foreign Key :

Structure Tabel : \{sp_Kode, sp_Nama, sp_Alamat, sp_Telpon \}

\begin{tabular}{|c|c|c|}
\hline \multicolumn{3}{|l|}{ tbISupplier } \\
\hline Field Name & Data Type & \\
\hline sp_Nama & Text & Nama Supplier \\
\hline sp_Alamat & Text & Alamat Supplier \\
\hline sp_Telpon & Text & Nomor Telpon Supplier \\
\hline
\end{tabular}

Tabel 2. Struktur Supplier

c. Tabel Master: Barang

Primary Key : br_Kode

Foreign Key : -

Structure Tabel : $\{$ br_Kode, br_Nama, br_Satuan, br_Harga $\}$

\begin{tabular}{|c|c|c|c|}
\hline $6=$ & Field Name & Data Type & \\
\hline \multirow[t]{4}{*}{8} & br_Kode & Text & Kode Barang \\
\hline & br_Nama & Text & Nama Barang \\
\hline & br_Satuan & Text & Satuan Barang \\
\hline & br_Harga & Number & Harga Barang \\
\hline
\end{tabular}

Tabel 3. Struktur Barang 
d. Tabel Transaksi: Purchase Order (PO)

Primary Key : po_No

Foreign Key : us_Nik, sp_Kode

Structure Tabel : \{ po_No, po_Tanggal, po_Total, sp_Kode, us_Nik \}

\begin{tabular}{|l|l|l|}
\hline \multicolumn{2}{c}{ Field Name } & \multicolumn{2}{c}{ Data Type } \\
\hline 8 & Text & Nomor Purchase Order \\
\hline po_No & Text & Tanggal Purchase Order \\
\hline po_Tanggal & Number & Total Purchase Order \\
\hline po_Total & Text & Kode Supplier \\
\hline sp_Kode & Text & Nomor Induk Karyawan \\
\hline us_Nik & St & \\
\hline
\end{tabular}

Tabel 4. Struktur Purchase Order

e. Tabel Transaksi: Surat Jalan (SJ)

Primary Key : sj_No

Foreign Key : \{ po_No

Structure Tabel : $\{$ sj_No, sj_Tanggal, po_No $\}$

\begin{tabular}{|c|c|c|c|}
\hline \multicolumn{4}{|c|}{ tbISj } \\
\hline & Field Name & Data Type & \\
\hline 8 & sj_No & Text & Nomor Surat Jalan \\
\hline & sj_Tanggal & Date/Time & Tanggal Surat Jalan \\
\hline & po_No & Text & Nomor Purchase Order \\
\hline
\end{tabular}

Tabel 5. Struktur Surat Jalan

f. Tabel Transaksi: Invoice

Primary Key : in_No

Foreign Key : sj_No

Structure Tabel : $\{$ in_No, in_Tanggal, in_Jatuh_tempo, sj_No $\}$

\begin{tabular}{|l|l|l|}
\hline \multicolumn{2}{|c|}{ tbllnvoice } & \multicolumn{2}{c|}{ Data Type } \\
\hline in_No & Text & Nomor Invoice \\
\hline in_Tanggal & Date/Time & Tanggal Invoice \\
\hline in_Jatuh_Tempo & Text & Jatuh Tempo Invoice \\
\hline sj_No & Text & Nomor Surat Jalan \\
\hline
\end{tabular}

Tabel 6. Struktur Invoice

g. Tabel Transaksi: Faktur Pajak

Primary Key : fk_No

Foreign Key : in_No

Structure Tabel : $\{$ fk_No, fk_Tanggal, In_No \}

\begin{tabular}{|l|l|l|}
\hline \multicolumn{2}{|c}{ tblFaktur } & \multicolumn{2}{c}{ Data Type } \\
\hline fk_No & Text & Nomor Faktur Pajak \\
\hline fk_Tanggal & Date/Time & Tanggal Faktur Pajak \\
\hline in_No & Text & Nomor Invoice \\
\hline
\end{tabular}

Tabel 7. Struktur Faktur Pajak 
h. Tabel Transaksi: Tanda Terima Invoice

\begin{tabular}{|c|c|c|c|}
\hline \\
\hline \multirow{3}{*}{\multicolumn{4}{|c|}{$\begin{array}{ll}\text { Primary Key } & \text { : } \\
\text { Foreign Key } & \text { : } \\
\text { Structure Tabel } & \text { : }\end{array}$}} \\
\hline & & & \\
\hline & & & \\
\hline \multicolumn{4}{|c|}{ tblTandaterima } \\
\hline \multicolumn{2}{|r|}{ Field Name } & Data & \\
\hline \multirow[t]{4}{*}{8} & ti_No & Text & Nomor Tanda Terima Invoice \\
\hline & ti_-Tanggal & Date/Time & Tanggal Tanda Terima Invoice \\
\hline & in_No & Text & Nomor Invoice \\
\hline & fk_No & Text & Nomor Faktur Pajak \\
\hline
\end{tabular}

Tabel 8. Struktur Tanda Terima Invoice

\subsection{Grafik Monitoring Pembayaran Hutang}

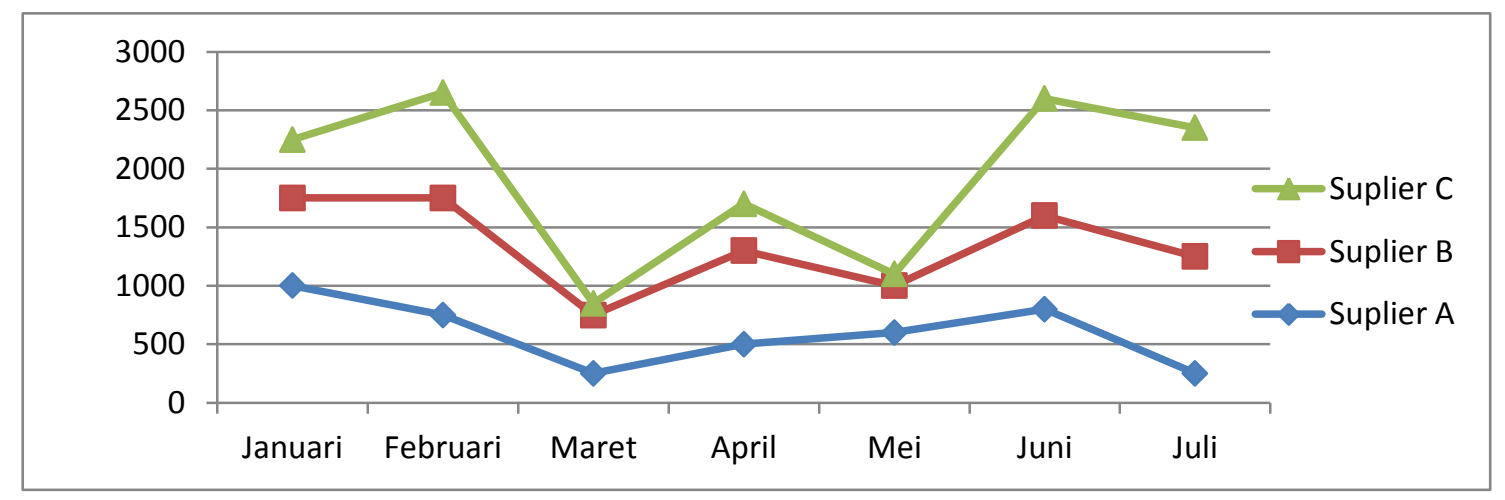

Grafik diatas (gambar 6) merupakan grafik monitoring pembayaran suplier berdasarkan waktu (bulan). Hal ini bisa membantu manajemen dalam menunjang keputusan guna pembayaran mana yang menjadi prioritas pembayaran.

\subsection{Diagram HIPO}

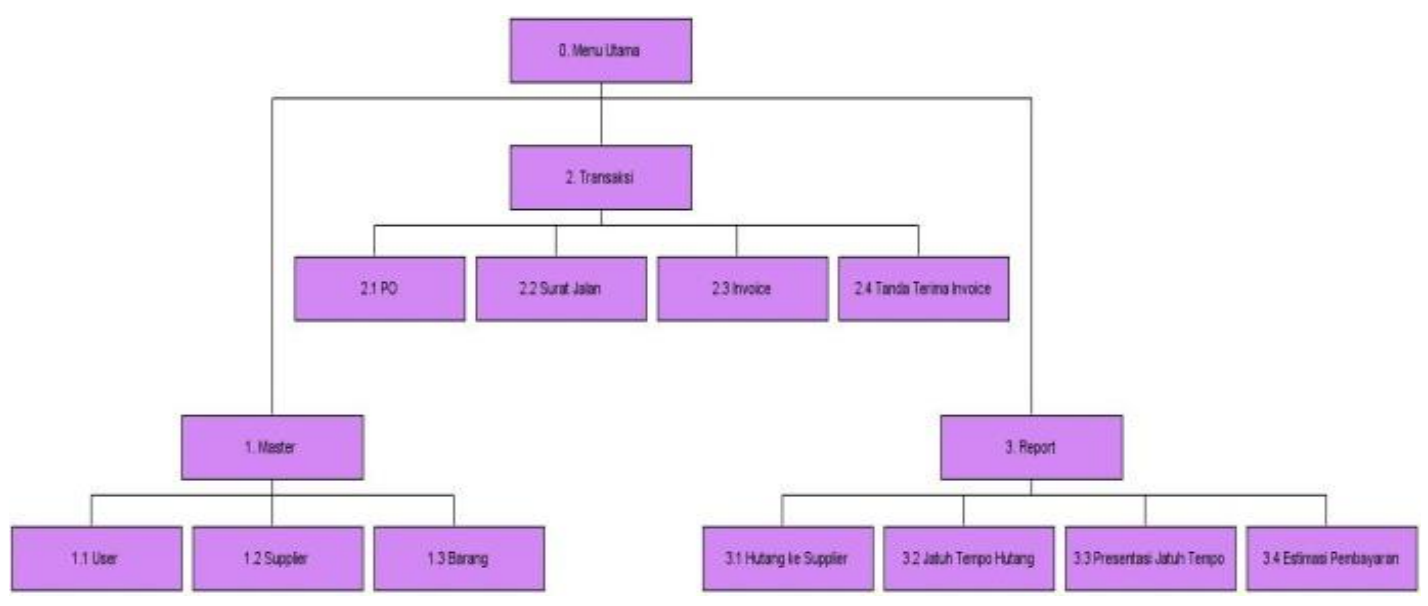

Gambar 7. Diagram HIPO

Untuk menggambarkan stuktur menu dari sistem yang dirancang dapat digambarkan dengan diagram HIPO (Hierarchy Input Process Output). Untuk menyediakan suatu struktur guna memahami fungsi-fungsi dari program. Terlihat dari diagram HIPO diatas (gambar 7) terdapat 1 (satu) fungsi utama (digram 0) dan 3 (tiga) fungsi dibawahnya, yaitu fungsi menu 
master (diagram 1), menu transaksi (diagram 2) dan menu report (diagram 3). Didalam fungsi menu master (diagram 1) terdapat 3 (tiga) fungsi sub menu yaitu fungsi menu pengelolaan data user (diagram 1.1), pengelolaan data suplier (diagram 1.2) dan pengelolaan data barang (diagram 1.3). Didalam fungsi menu transaksi (diagram 2) terdapat 4 (empat) fungsi fungsi sub menu yaitu fungsi menu pengelolaan data po (diagram 2.1), pengelolaan data surat jalan (diagram 2.2), pengelolaan data invoice (diagram 2.3) dan pengelolaan data tanda terima invoice (diagram 2.4). Didalam fungsi report (diagram 3) terdapat 4 (empat) fungsi sub menu yaitu fungsi menu pengelolaan data tagihan supplier (diagram 4.1), pengelolaan jatuh tempo hutang (diagram 4.2), pengelolaan presentasi jatuh tempo (diagram 4.3) dan pengelolaan data estimasi pembayaran (diagram 3.4).

\subsection{Rancangan Tampilan}

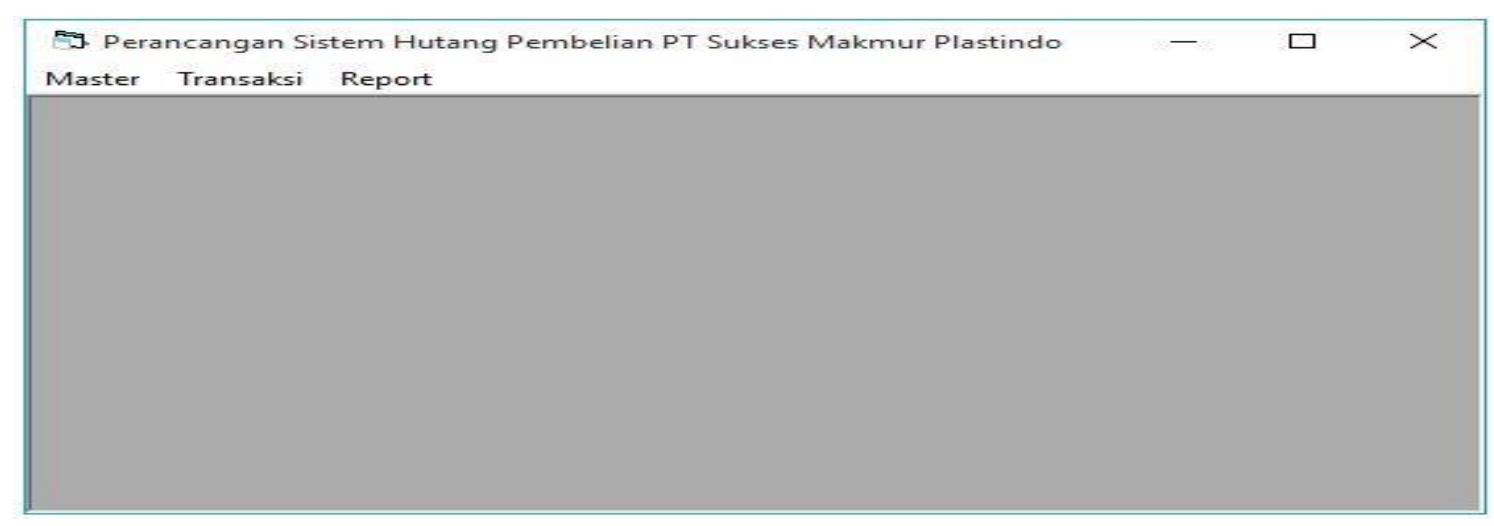

Gambar 8. Tampilan Utama

Terlihat pada tampilan layar diatas (gambar 8) merupakan tampilan layar utama yang terdiri dari menu master, menu transaksi dan menu report. [10]

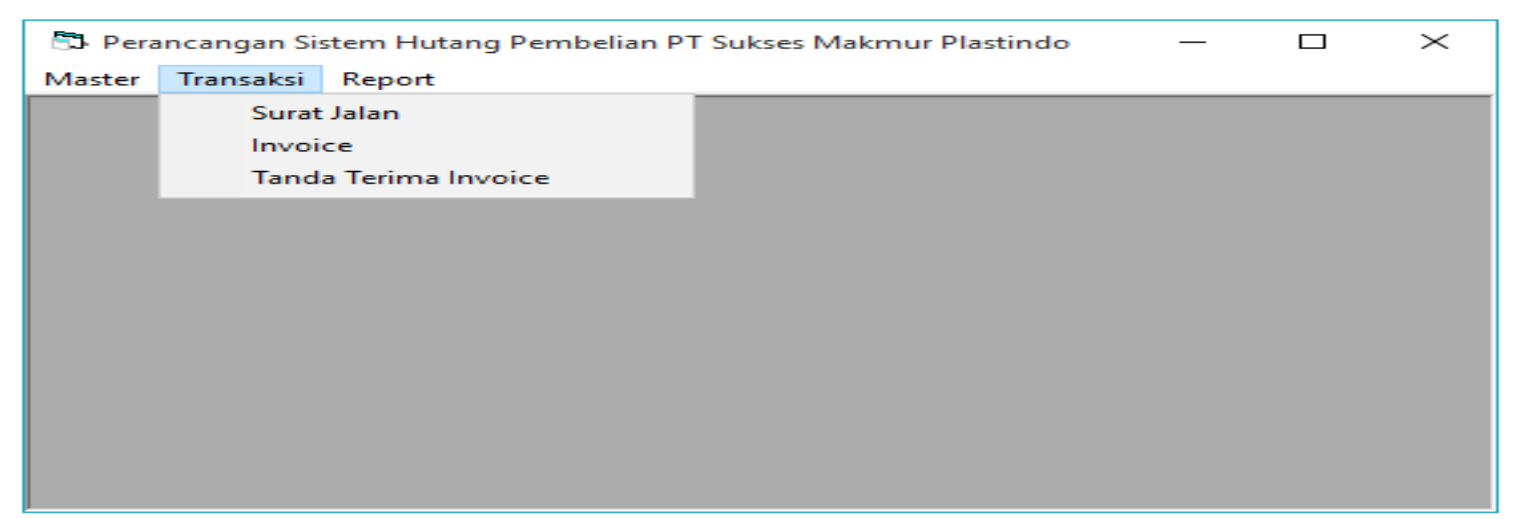

Gambar 9. Tampilan Menu Transaksi

Terlihat pada tampilan layar diatas (gambar 9) merupakan tampilan layar utama yang terdiri dari menu master, menu transaksi dan menu report, dimana menu transaksi memiliki sub menu surat jalan, sub menu invoice dan sub menu tanda terima invoice. 


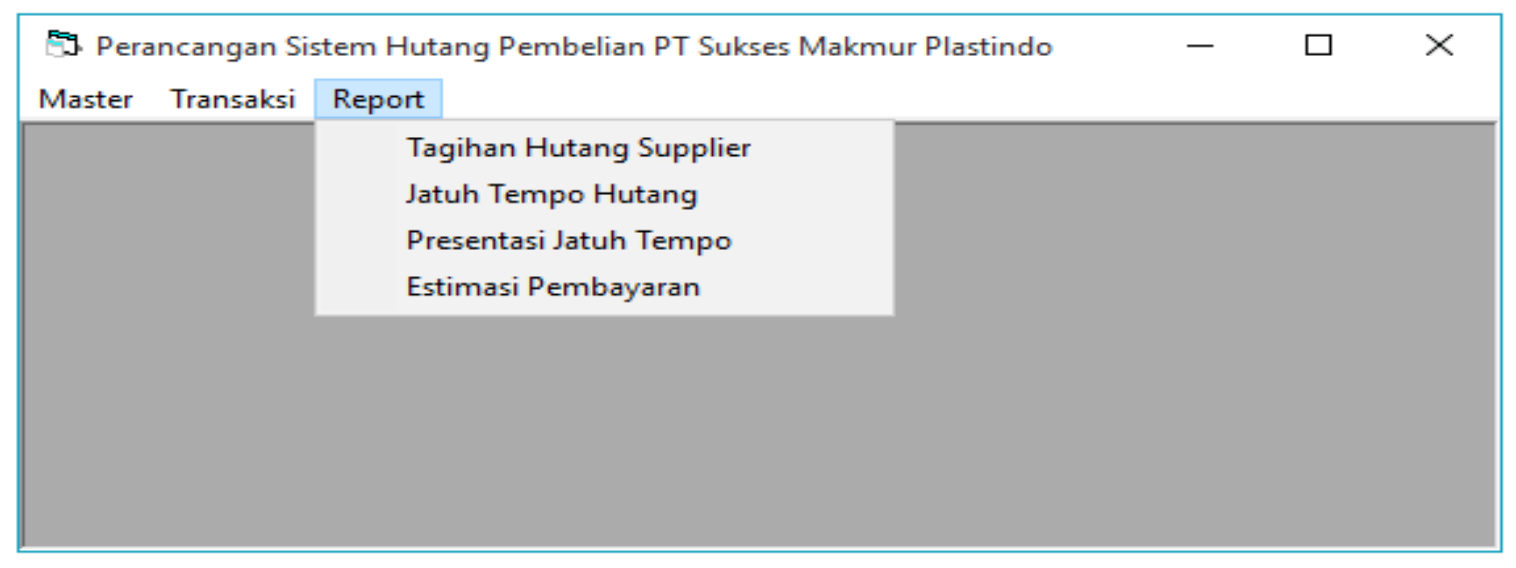

Gambar 10. Tampilan Menu Report

Terlihat pada tampilan layar diatas (gambar 10) merupakan tampilan layar utama yang terdiri dari menu master, menu transaksi dan menu report, dimana menu report memiliki sub menu tagihan hutang supplier, jatuh tempo hutang, presentasi jatuh tempo dan estimasi pembayaran.

\subsection{Query Penciptaan Informasi}

\section{Query Menciptakan Laporan Purchase Order:}

SELECT tblPo.po_No, tblPo.po_Tanggal, tblPo.po_Total

FROM ((()tblPo INNER JOIN ((tblFaktur INNER JOIN tblInvoice ON tblFaktur.in_No = tblInvoice.in_No) INNER JOIN tblSj ON tblInvoice.sj_No = tblSj.sj_No) ON tblPo.po_No = tblSj.po_No) INNER JOIN tblSupplier ON tblPo.sp_Kode = tblSupplier.sp_Kode) INNER JOIN tblTandaterima ON tblInvoice.in_No = tblTandaterima.in_No) INNER JOIN tblUser ON tblPo.us_Nik = tblUser.us_Nik) INNER JOIN (detailSj INNER JOIN (tblBarang INNER JOIN detailPo ON tblBarang.br_Kode $=$ detailPo.br_Kode) ON detailSj.br_Kode = tblBarang.br_Kode)

ON (tblPo.po_No = detailPo.po_No) AND (tblSj.sj_No= detailSj.sj_No).

\section{Query Menciptakan Laporan Invoice:}

SELECT tblInvoice.in_No, tblInvoice.in_Tanggal, tblInvoice.in_Jatuh_Tempo, tblSupplier.sp_Nama FROM ((()tblPo INNER JOIN ((tblFaktur INNER JOIN tblinvoice ON tblFaktur.in_No = tblInvoice.in_No) INNER JOIN tblSj ON tblInvoice.sj_No $=$ tblSj.sj_No) ON tblPo.po_No $=$ tblSj.po_No) INNER JOIN tblSupplier ON tblPo.sp_Kode = tblSupplier.sp_Kode) INNER JOIN tblTandaterima ON tblinvoice.in_No = tblTandaterima.in_No) INNER JOIN tblUser ON tblPo.us_Nik = tblUser.us_Nik) INNER JOIN (detailSj INNER JOIN (tblBarang INNER JOIN detailPo ON tblBarang.br_Kode = detailPo.br_Kode) ON detailSj.br_Kode = tblBarang.br_Kode) ON (tblPo.po_No = detailPo.po_No) AND (tblSj.sj_No = detailSj.sj_No);

\section{Query Menciptakan Laporan Presentasi Jatuh Tempo:}

SELECT tblInvoice.in_No, tblInvoice.in_Tanggal, tblInvoice.in_Jatuh_Tempo, tblSupplier.sp_Nama FROM (()(tblPo INNER JOIN ((tblFaktur INNER JOIN tblinvoice ON tblFaktur.in_No = tblInvoice.in_No) INNER JOIN tblSj ON tblInvoice.sj_No = tblSj.sj_No) 
ON tblPo.po_No = tblSj.po_No) INNER JOIN tblSupplier ON tblPo.sp_Kode = tblSupplier.sp_Kode) INNER JOIN tblTandaterima ON tblInvoice.in_No = tblTandaterima.in_No) INNER JOIN tblUser ON tblPo.us_Nik = tblUser.us_Nik) INNER JOIN (detailSj INNER JOIN (tblBarang INNER JOIN detailPo ON tblBarang.br_Kode = detailPo.br_Kode) ON detailSj.br_Kode = tblBarang.br_Kode) ON (tblPo.po_No = detailPo.po_No) AND (tblSj.sj_No=detailSj.sj_No);

\section{Query Menciptakan Laporan Presentasi Masa Jatuh Tempo:}

SELECT tblInvoice.in_No, tblInvoice.in_Tanggal, tblInvoice.in_Jatuh_Tempo, tblSupplier.sp_Nama FROM (((t)lPo INNER JOIN ((tblFaktur INNER JOIN tblinvoice ON tblFaktur.in_No = tblInvoice.in_No) INNER JOIN tblSj ON tblInvoice.sj_No = tblSj.sj_No) ON tblPo.po_No $=$ tblSj.po_No) INNER JOIN tblSupplier ON tblPo.sp_Kode = tblSupplier.sp_Kode) INNER JOIN tblTandaterima ON tblinvoice.in_No = tblTandaterima.in_No) INNER JOIN tblUser ON tblPo.us_Nik = tblUser.us_Nik) INNER JOIN (detailSj INNER JOIN (tblBarang INNER JOIN detailPo ON tblBarang.br_Kode = detailPo.br_Kode) ON detailSj.br_Kode = tblBarang.br_Kode) ON (tblPo.po_No = detailPo.po_No) AND (tblSj.sj_No = detailSj.sj_No);

\section{Query Menciptakan Laporan Estimasi Pembayaran Next PO:}

SELECT tblInvoice.in_No, tblInvoice.in_Tanggal, tblInvoice.in_Jatuh_Tempo, tblSupplier.sp_Nama FROM (((t)lPo INNER JOIN ((tblFaktur INNER JOIN tblinvoice ON tblFaktur.in_No = tblInvoice.in_No) INNER JOIN tblSj ON tblInvoice.sj_No = tblSj.sj_No) ON tblPo.po_No $=$ tblSj.po_No) INNER JOIN tblSupplier ON tblPo.sp_Kode = tblSupplier.sp_Kode) INNER JOIN tblTandaterima ON tblInvoice.in_No = tblTandaterima.in_No) INNER JOIN tblUser ON tblPo.us_Nik = tblUser.us_Nik) INNER JOIN (detailSj INNER JOIN (tblBarang INNER JOIN detailPo ON tblBarang.br_Kode = detailPo.br_Kode) ON detailSj.br_Kode = tblBarang.br_Kode) ON (tblPo.po_No = detailPo.po_No) AND (tblSj.sj_No=detailSj.sj_No);

\section{KESIMPULAN}

Beberapa perusahaan masih menggunakan microsoft excel, selain itu juga tidak terdapat notifikasi atau kontrol khusus sebagai peringatan, purchase order dan faktur pajak tidak terkontrol, sehingga sering kali terjadi kelebihan pembayaran hutang pajak dari yang seharusnya, dan hal ini menyebabkan keterlambatan dalam pengambilan keputusan. Terjadinya beberpa masalah yang dialami dalam keadaan darurat yang disebabkan adanya kesalahan informasi antara dept finance, dept purchasing dan manager keuangan, sehingga mengalami kesulitan mendapatkan informasi mengenai pembayaran purchase order, yang meliputi informasi seberapa banyak purchase order yang sudah di buat dan purchase order mana saja yang harus jadwalkan untuk dibayarkan sesuai tanggal jatuh tempo. Sehingga perencanaan pengeluaran bulanan yang terkait dengan tanggal jatuh tempo hutang dagang tidak termonitoring dan tidak terupdate dengan baik yang mengakibatkan terhambatnya proses administrasi dan kegiatan lainya yang dilakukan di perusahaan. Usulan sistem informasi hutang pembelian ini sebagai dasar untuk pengambilan keputusan dalam perencanaan dan pelaksanaan proses pembayaran dihaapkan mampu menjadi solusi untuk meminimalisir keterlambatan dalam pembayaran. 


\section{DAFTAR PUSTAKA}

[1] Junaidi, Junaidi, Abdul Roji, and Kharis Munawar. "Konsep Otomatisasi Sistem Pembayaran SPP Online Untuk Mengurangi Tingkat Keterlambatan." Proceedings Konferensi Nasional Sistem dan Informatika (KNS\&I) (2015).

[2] Rijan, Yunirman, and Ira Koesoemawati. "Cara Mudah Membuat Surat Perjanjian/Kontrak dan Surat Penting Lainnya." Raih Asa Sukses, Depok (2009).

[3] Junaidi, Junaidi, Ladyca Anugrah, and Adhitya Dwi Pancasakti. "Model Aplikasi Monitoring Sistem Absensi Sidik Jari Sebagai Pendukung Keputusan Untuk Penilaian Kinerja Pegawai." Proceedings Konferensi Nasional Sistem dan Informatika (KNS\&I) (2015).

[4] Sugianto. 2013. "Perancangan Sistem Informasi Penjualan Pada Butik Luwes Fashion Kecamatan Tulakan." Indonesian Jurnal on Computer Science-Speed (IJCSS) Vol 2 No I ISSN:2302-1136 (2013).

[5] Junaidi, Junaidi, Abdul Roji, and Kharis Munawar. "Konsep Otomatisasi Sistem Pembayaran SPP Online Untuk Mengurangi Tingkat Keterlambatan." Proceedings Konferensi Nasional Sistem dan Informatika (KNS\&I) (2015).

[6] Henderi, Henderi, Junaidi Junaidi, and Tubagus Ahmad Harja Kusuma. "Dashboard Monitoring System Penjualan Dan Reward Mobile Kios PT. Telekomunikasi Seluler." Semantik 2.1 (2012).

[7] Junaidi, Junaidi, Ridwan Arifin, and Amanda Septiani. "Rancang Bangun Aplikasi Sistem Inventory Berbasis Desktop Menggunakan JSE." Proceedings Konferensi Nasional Sistem dan Informatika (KNS\&I) (2015).

[8] Junaidi, Junaidi, Novi Cholisoh, and Nur Hasanah. "Rancang Bangun Sistem Manajemen Aset IT Untuk Pencatatan History Maintenance Sebagai Pendukung Keputusan." SENSI Journal 4.2 (2018): 220-231.

[9] Junaidi, Junaidi, Retno Setianingsih, and Khusnul Khotimah. "Rancang Bangun Sistem Penerimaan Dan Pengeluaran Barang Menggunakan Java Aplikasi." Proceedings Konferensi Nasional Sistem dan Informatika (KNS\&I) (2015).

[10] Junaidi, Junaidi, Sugeng Santoso, and Lusyani Sunarya. "Rekayasa Teknik Pemrograman Pencegahan Dan Perlindungan Dari Virus Lokal Menggunakan API Visual Basic." CCIT Journal 1.2 (2008): 134-153. 